\title{
Sail Training, Vocational Socialisation and Merchant Seafarer Careers: The German Initiative in the $1950 \mathrm{~s}^{1}$
}

\section{Alston Kennerley}

\begin{abstract}
Tout au long du 20ème siècle la pertinence de l'expérience pratique dans les navires hauturiers à voile carrée avec de futures carrières de marin dans les navires motorisés a été discutée et remise en cause. Il restent aujourd'hui des pays qui fournissent une telle expérience pour des officiers stagiaires, et il y a un soutien mondial pour donner de l'expérience de la voile aux jeunes dans le cadre du développement caractériel indépendamment du futur métier. La discussion ici se concentre sur l'initiative allemande des années 50, en recherchant des avis personnels au sujet du contexte et du but opérationnel, par le moyen de questionnaires sur l'expérience personnelle de la voile et du métier de marin qui a pu suivre. Les résultats prouvent que les répondants étaient généralement favorables à la possibilité de formation en termes de la gamme étendue des qualifications personnelles engendrées, et que le coût et l'effort sont valables.
\end{abstract}

The history of merchant seafarer training is probably almost as old as deep sea seafaring itself. It can certainly be identified from medieval times, at least in Britain through the adoption of craft guild progression structures: apprenticeship, journeyman craftsman (mate), master craftsman. In British seafaring two levels of apprenticeship evolved: seaman apprenticeship and officer apprenticeship. With the opening of the oceans in the fifteenth and sixteenth centuries, educational dimensions, especially navigation, began to be taught ashore as well as at sea, to those destined for command. Until well into the nineteenth century, skills aspects, grouped under the term seamanship, were always learned or taught through example and experience aboard ships engaged in commercial trading. With the advent of the power-driven merchant ship, the expectation

1 An earlier version of this paper was presented at the $11^{\text {th }}$ Maritime History Conference of the Association for the History of the Northern Seas Conference in Bremen, 1-5 August 2003, in a session attended by members of the Pamir Passat Vereinigung (PPV). Members of PPV responded to a questionnaire discussed in this paper. An abstract from that version of the paper appeared in a German transalation by Kapitän Peter Kraus (Passat 1952), in the society's in-house newsletter: Alston Kennerley, "Besatzungsmitglieder von Pamir und Passat auf See und an Land seit 1952," PPV Logbuch XXVI, no. 3 (December 2003): 12-15. The author is indebted to the anonymous referees of the original paper for their helpful suggestions.

The Northern Mariner/le marin du nord, XX No. 4, (October 2010), 385-405 
persisted that seafarers employed in steamships would have trained first in sail. But towards the end of the nineteenth century it was becoming increasingly clear that commercial sail was being killed off, that sail trained men would be in short supply, and that either future training must be in power-driven vessels, or that special provision must be made for seamanship training ashore or in dedicated training vessels. This made training expensive. A commitment to funding from the shipping industry, from the state, or through charities became essential.

Implicit in the persistence of a desire for sail trained crews was a belief that it offered the trainee something extra connected with character development, as it seemed that only a small proportion of the skills associated with sail propulsion transferred to the power driven vessel. It is this dimension which drove developments throughout the twentieth century in training through the sea or in dedicated sail training ships for youngsters regardless of intended career. Examples include the Outward Bound Sea School movement and the activities of the Sail Training Association in Britain, and similar structures in the majority of maritime countries. Some countries continued to value sail training as an initial stage in the preparation of young seafarers for careers in their commercial or military navies, a notable exception being Britain. In Germany, for example, experience in sail was

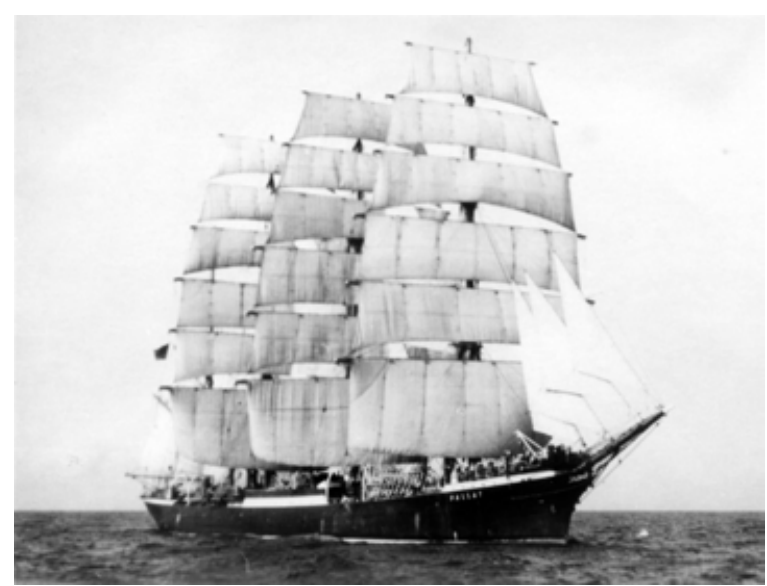

Illustration 1: German four mast barque, Passat, at sea in a light breeze, 1952. [Author's collection.] required for progression in commercial ships until the end of the 1950s, which was provided through the sail fishing fleet in the Baltic Sea, and between 1951 and 1958 by a new sail training ship initiative involving the famous four masted barques Pamir and Passat. $^{2}$ The Hanseatic port Bremen, and the River Weser, have a long association with sail training ship building and operation. It was from here that the author of this paper departed twice in 1952 aboard the Frachtsegelschulschiff Passat, in January from Brake and in June from Bremen.

In order to see the 1950s in context, the first part of the discussion will be devoted to an overview of the history and approaches to merchant seafarer training with particular reference to sail training and the arguments for and against that approach. The second section draws on the personal experience noted above. This will not be set out in

2 SV Pamir: built 1905 by Blöhm \& Voss, Hamburg; original owner F. Laeisz, Hamburg; gross tonnage 3020. Owned in New Zealand during World War II. In 1951 acquired by German interests and converted for training; auxiliary engine fitted. SV Passat: built 1911 by Blohm \& Voss, Hamburg; original owner F. Laeisz, Hamburg; gross tonnage (1951) 3181. In 1951 acquired by German interests and converted for training; auxiliary engine fitted. 
detail as that was attempted in an earlier paper published in $1994 .^{3}$ However it will review the sociological context examined there, notably influences on career choice and occupational socialization, and will draw on the author's personal log of the voyages, not used previously, to present that experience. The final section will be devoted to the careers of cadets who trained in Pamir or Passat in the 1950s, through an analysis of the responses to a questionnaire circulated amongst members of the Pamir Passat Vereinigung. ${ }^{4}$

Over the years, sea training schemes have taken many different forms and involved a wide variety of vessel types. Some have been based in shore establishments, some in permanently moored ships, and many in seagoing vessels. Shore establishments, such as that at Priwall-Travemünde (1952), ${ }^{5}$ and the stationary training ships, were river based and delivered experience afloat through rowing and sailing in open boats such as ship's lifeboats. Many operated small seagoing tenders, usually yachts, taking short coastal voyages. The stationary vessels were usually fairly large ship or barque rigged vessels and could deliver experience aloft, though only as drills. The majority of seagoing training ships, which ranged in size from about 100 to about 5000 tons, had some form of square rig and were increasingly fitted with auxiliary engines.

Underhill's catalogue of training ships, published in 1956, contains 252 entries related to the periods ships were used for training purposes. ${ }^{6}$ His earliest is Magnus Stenbock owned by the Gothenburg Sailors' Society, a stationary vessel used for training between 1838 and 1850. Curiously he misses the [British] Marine Society's series of stationary training ships which commenced training in $1786,{ }^{7}$ and the network of charitable stationary rating and officer training ships established in Britain from the midnineteenth century. ${ }^{8}$ His list contains a number of duplications where ships changed names or trained in two separate phases. Thus the four masted barque Magdalene Vinnen is shown training between 1921 and 1936, and as Kommodore Johnson between 1936 and

3 Alston Kennerley, "Occupational Conditioning: First Voyage in Passat," in Stephen Fisher, ed., Man and the Maritime Environment (Exeter, 1994), 210-232.

4 Pamir Passat Association. Members have served in one or other of the ships, or in both.

5 Kapitän Herman Heuer, master of Passat for its outward passage from Brake to Rio Grande do Sul (Brazil) in 1952, left the ship to return and establish the Schiffsjungenschule at Priwall, Travemünde.

6 Harold A. Underhill, Sail Training and Cadet Ships (Glasgow: Brown, 1956), appendix 1. See also Alston Kennerley, "Training Ships," in John B. Hattendorf, ed., Oxford Encyclopedia of Maritime History, Volume 4 (Oxford, 2007), 190-192.

7 J.S. Taylor, Jonas Hanway, Founder of the Marine Society: Charity and Policy in Eighteenth-Century Britain (London, 1985), 177-8.

8 Alston Kennerley, "Ratings for the Mercantile Marine: the Roles of Charity, the State and Industry in the Pre-Service Education and Training of Ratings for the British Merchant Navy, 1879-1939," History of Education XXVIII, no. 1 (1999): 31-51; Alston Kennerley, "Civilian Stationary Training Ships and Other Mercantile Marine Education on or Adjacent to the River Thames," in Roger Owen, ed., Shipbuilding and Ships on the Thames: Proceedings of a Third Symposium, Held on 18 February 2006 at Greenwich Maritime Institute, Old Royal Naval College, Greenwich (West Wickham, Kent, UK, 2007), 104-129. 
1945. ${ }^{9}$ She would later re-appear as Sedov (still training). Passat has two entries, 1927-32 (owned by Ferdinand Laeisz, Hamburg) and from 1951 (Heinz Schliewen, Hamburg). Pamir is also entered twice: 1943-50 (New Zealand Government) and from 1951 (Heinz Schliewen). Schliewen led the financial rescue and renovation of Pamir and Passat in response to the initiative of a group led by Kapitän Grubbe in 1950-51.

\section{Table 1 - Training Vessels Operated in January 2003, by Members of the International Association of Maritime Universities}

\begin{tabular}{|c|c|c|c|c|c|c|c|c|}
\hline \multicolumn{3}{|l|}{ Ship's: } & \multirow{2}{*}{$\begin{array}{l}\text { Sail or } \\
\text { Power }\end{array}$} & & \multirow{2}{*}{$\begin{array}{l}\mathrm{B} \\
\mathrm{m}\end{array}$} & \multirow{2}{*}{\begin{tabular}{l|l}
$\operatorname{Dr}$ & $C$ \\
$m$ & $n$
\end{tabular}} & \multirow{2}{*}{\multicolumn{2}{|c|}{\begin{tabular}{l|l} 
Cr & Cdts \\
no. & no.
\end{tabular}}} \\
\hline Establishment & Country & Name & & & & & & \\
\hline Adm. Makarov State Maritime Academy & Russia & Mir & S & 110 & 14 & 7 & 55 & 144 \\
\hline Arab Academy ....Maritime Transport & Egypt & Aida IV & $\mathrm{P}$ & 88 & 15 & 5 & 60 & 160 \\
\hline Australian Maritime College & Australia & Wyuna & $\mathrm{P}$ & 64 & 12 & 5 & & \\
\hline California Maritime Academy & USA & Golden Bear & $\mathrm{P}$ & 153 & 22 & 10 & 31 & 300 \\
\hline Constanta Maritime University & Rumania & Neptun & $\mathrm{P}$ & 122 & 17 & 7 & 22 & 120 \\
\hline Dalian Maritime University & China & Yu Long & $\mathrm{P}$ & 140 & 21 & 8 & 30 & 120 \\
\hline $\begin{array}{l}\text { Far East. State Tech. Fisheries } \\
\text { University }\end{array}$ & Russia & Pallada & $\mathrm{S}$ & 109 & 14 & 7 & 51 & 144 \\
\hline Fish \& Marine Inst. Memorial U. Nfld & Canada & Luis M Lauzier & $\mathrm{P}$ & 32 & 8 & 2 & 7 & 30 \\
\hline Gdynia Maritime University & Poland & Dar Mlodziezy & $\mathrm{S}$ & 109 & 14 & 7 & 31 & 136 \\
\hline Gdynia Maritime University & Poland & Horyzont II & $\mathrm{P}$ & 56 & 11 & 5 & 14 & 43 \\
\hline Istanbul Tech U. Maritime Faculty & Turkey & Akdeniz & $\mathrm{P}$ & 144 & 19 & 6 & 80 & 350 \\
\hline $\begin{array}{l}\text { Kobe University of the Mercantile } \\
\text { Marine }\end{array}$ & Japan & $\begin{array}{l}\text { Fukae Maru } \\
\text { III }\end{array}$ & $\mathrm{P}$ & 50 & 10 & 4 & 12 & 52 \\
\hline Korea Maritime University & Korea & Hanbada & $\mathrm{P}$ & 100 & 15 & 5 & 54 & 174 \\
\hline Korea Maritime University & Korea & Hannara & $\mathrm{P}$ & 103 & 15 & 5 & 50 & 152 \\
\hline Kyiv State Maritime Academy & & Svyata Olga & $\mathrm{P}$ & 122 & 17 & 7 & 7 & 30 \\
\hline Maine Maritime Academy & USA & State of Maine & $\mathrm{P}$ & 153 & 22 & 10 & 50 & 200 \\
\hline Mokpo National Maritime University & Korea & Sea Yudal & $\mathrm{P}$ & 103 & 15 & 5 & 50 & 152 \\
\hline Mokpo National Maritime University & Korea & Udal & $\mathrm{P}$ & 93 & 15 & 7 & 50 & 250 \\
\hline Nicola Y Vaptsarov Naval Academy & Bulgaria & 421 & $\mathrm{P}$ & 68 & 10 & 3 & 42 & 94 \\
\hline Nicola Y Vaptsarov Naval Academy & Bulgaria & Kaliakra & $\mathrm{S}$ & 48 & 8 & 4 & & \\
\hline Odessa State Maritime University & & Druzhba & $\mathrm{S}$ & 109 & 14 & 7 & 31 & 136 \\
\hline Rijeka College of Maritime Studies & & Nase More & $\mathrm{P}$ & 31 & 7 & 3 & 5 & 20 \\
\hline Satakunta Poly. Sector Tech. Marit. Mgt & Finland & Fanny & $\mathrm{P}$ & 34 & 7 & 4 & & \\
\hline Satakunta Poly. Sector Tech. Marit. Mgt & Finland & Meteor & $\mathrm{P}$ & 39 & 9 & 5 & & \\
\hline Satakunta Poly. Sector Tech. Marit. Mgt & Finland & Turumaa & $\mathrm{S}$ & 74 & 9 & 3 & & \\
\hline Shanghai Maritime University & China & Yu Feng & $\mathrm{P}$ & 140 & 21 & 8 & 24 & 130 \\
\hline State U. of New York Maritime College & USA & Empire State & $\mathrm{P}$ & 172 & 23 & 10 & 14 & 425 \\
\hline Tokyo University of Mercantile Marine & Japan & Shioji Maru & $\mathrm{P}$ & 50 & 10 & 4 & 12 & 50 \\
\hline
\end{tabular}

Source: IAMU News [International Association of Maritime Universities], no.8 (January 2003): 875. Notes: S sail propelled; P power propelled; L length; B breadth; Dr draft; Cr crew; Cdts Cadets. Ship dimensions rounded to nearest metre.

9 SV Magdalene Vinnen: built 1921 by F.Krupp, Kiel; original owners F.A. Vinnen, Bremen; gross tonnage 3476. 1936 acquired by North German Lloyd, renamed Kommodore Johnsen. 1945 acquired by USSR, renamed Sedov. 
What all these establishments and ships had in common was a focus on the accepted core of sailing ship seamanship: knotting and splicing, purchases, detailed knowledge of the rigging, setting sails and furling, steering, magnetic compass, understanding and obeying orders, teamwork, rapid response, ship's routine, watch keeping, household duties. Whether seagoing or not, they were invariably residential, emulating, at least to some extent, the enclosed environment of the ship. Generally there was a military feel to the culture, including the wearing of uniforms, which aped naval usage. This may be seen today in the square rigged ships of, for example, Russia or Poland, which participate in the so called Tall Ships races.

By no means all seagoing training ships have been sail propelled. From 1930 for example, the New York State Merchant Marine Academy operated the former U.S. Navy power driven vessel Empire State as its training vessel under an Act of

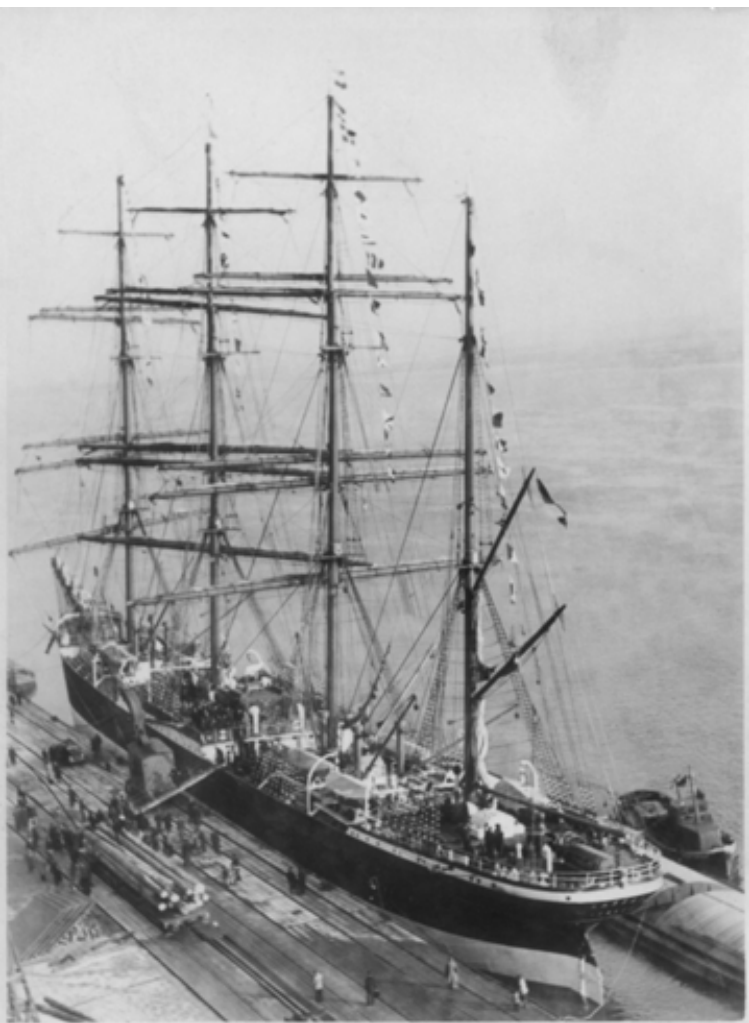

Illustration 2: German four mast barque, Passat, alongside Brake Pier, River Weser, Germany, in January 1952, ready to load a full cargo of cement. [Photograph: Hugo Krause, Brake. Author's collection.]

Congress of 1874, which required the Navy to provide training ships to be based at eleven U.S. ports. ${ }^{10}$ From Table 1 it will be apparent that power-driven vessels, often of substantial size, are now more favoured by training establishments than wind-driven vessels. With the exception of Finland and Russia, the absence of traditional maritime countries in north-west Europe from this list is striking. Of course these nations are usually represented in the Tall Ships races and other gatherings of sailing vessels, but mostly the trainees aboard are there for the experience rather than as a preparation for a career in merchant seafaring. ${ }^{11}$

Owing to Germany's extensive involvement in seafarer sail training in the first half of the twentieth century, the initiative of the 1950s was able to draw on ample

10 James C. Healy, Foc's'le and Glory Hole: a Study of the Merchant Seaman and His Occupation (New York, 1936), 40-3.

11 For an overview of vessels and practice involved in this aspect see: John Hamilton, Sail Training: the Message of the Tall Ships (Wellingborough, UK, 1988). This work names 92 ships. 
experience of building and operating such vessels and on the practice of training. In 1900 one of Germany's leading steamship companies, Norddeutscher Lloyd, showed exceptional foresight for a steamship company in recognising the need to address training. It purchased and converted the four masted barque, Albert Rickmers. ${ }^{12}$ Renamed Herzogin Sophie Charlotte, the company began operating it as a cargo carrying training ship carrying 84 cadets, and found itself with a runaway success. A second, new ship, Herzogin Cecilie, was added in 1902. ${ }^{13}$ At the same time the German Training Ship Association introduced the Grossherzogin Elisabeth and then the Princess Eitel Friedrich. ${ }^{14}$ Four other shipping companies also introduced sail training ships before World War I. For the period between the wars the involvement of the Magdalene Vinnen and Passat have already been noted. Of other vessels built or adapted for training by German owners, Schulschiff Deutschland became most well known. ${ }^{15}$ After World War II she became a stationary training ship. ${ }^{16}$ So it was that in 1950 Germany had a core of sail trained men, seamen, officers and masters, with the experience to man Pamir and Passat, and well able to sustain the tradition. ${ }^{17}$

While Britain had effectively abandoned sail training by 1914, concern about vocational training for merchant seafaring remained. That all future ratings should undergo a pre-sea course became the industry target with the establishment of the Gravesend Sea School in 1918, under joint shipowners-trade union management, though that aim was not achieved until the $1940 \mathrm{~s} .{ }^{18}$ For future officers the seafaring four year apprenticeship remained the standard approach. ${ }^{19}$ Typically, shipping companies placed

12 SV Albert Rickmers: 1894 built by Rickmers, Bremerhaven; 4 masted barque; gross tonnage 2591; acquired by North German Lloyd, renamed Herzogin Sophie Charlotte.

13 Basil Greenhill and John Hackman, Herzogin Cecilie: the Life and Times of a Four-Masted Barque (London,1991), 34-7. This work cites the following German studies of sail training: Heinz Burmeister, Segelschulschiff rund Kap Horn (Oldenberg, 1976); Elizabeth RoggeBallehr, Schule der See (Oldenberg, 1988); R. Schneider, An Bord unserer Schulschiffe, Leben und Treiben an Bord SM SM Seekadetten und Schiffsjungenschulschiffe (Munchen, 1901). SV Herzogin Cecile: built 1902 by Rickmers, Bremerhaven for North German Lloyd.; gross tonnage 3242; wrecked 1936.

14 SV Grossherzogin Elisabeth: built 1901by J.C. Tecklenborg, Geestemünde for Deutscher Schulschiff Verein; ship; gross tonnage 1260 tons. SV Princess Eitel Friedrich: built 1909 by Blöhm \& Voss for Deutscher Schilschiff Verein; ship; gross tonnage 1566.

15 SV Schulschiff Deutschland: built 1927 for Deutscher Schulschuff Verein; ship gross tonnage 1257.

16 Underhill, Sail Training and Cadet Ships, appendix 1.

17 For a recent study which touches on nautical training in the context of the history of merchant ship command see Jann Markus Witt, Master Next God? Der nordeuropäische Handelsschiffskapitän vom 17.bis zum 19. Jarhundert (Bremerhaven/Hamburg, 2001).

18 Alston Kennerley, "Vocational Further Education for British Merchant Navy Ratings: the National Sea Training Schools, 1942-1972," History of Education XXIX, no. 4 (2000): 301327.

19 On the British sea apprenticeship system see Alston Kennerley, "Aspirant Navigator: Training and Education at Sea During Commercial Voyages in British Merchant Ships, c. 
two or four apprentices in each of their vessels, until the 1960s often without pre-sea training. However, there were a few companies who operated commercial power driven vessels also as training ships. Between the wars, the British India Steam Navigation Company carried 39 cadets on each of its ships, Nardana and Australia, while the New Zealand Shipping Company carried 35 on each of its ships, Devon, Northumberland and Westmorland. ${ }^{20}$ The training schemes ensured experience of all seamanship tasks and of tasks cadets would become responsible for as junior officers. Training officers were carried, and there was a strong emphasis on continued study of the subjects in the Second Mate's examination. After 1945, these companies resumed this approach, and were joined by others

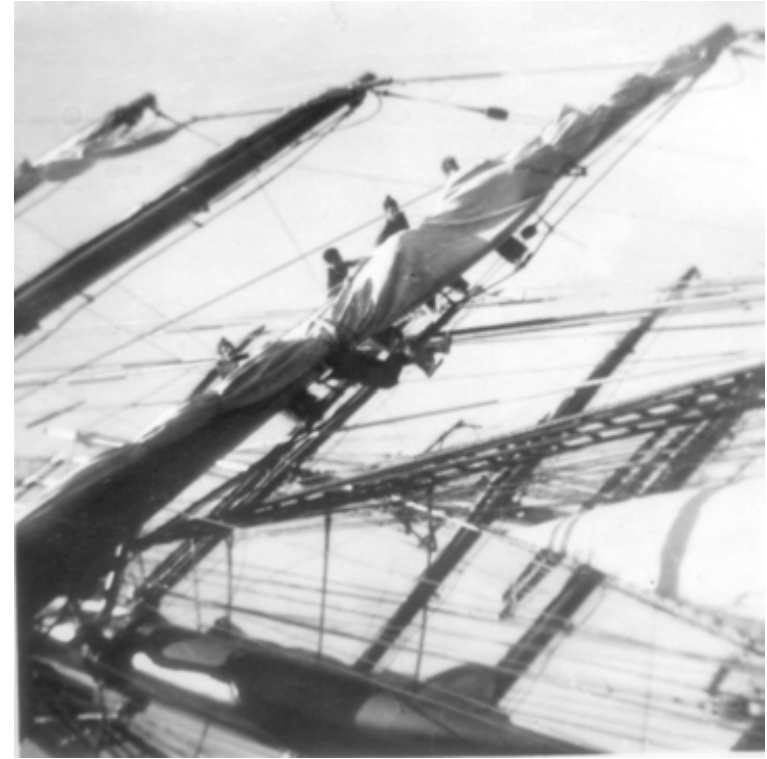

Illustration 3: Furling the fore sail aboard the German four mast barque, Passat, in 1952. Notice the man sitting on the foot rope passing a gasket. [Photograph: Author.] including Elder Dempster and Alfred Holt \& Co. (Blue Funnel). The operation of Holt's cargo liner MV Calchas in the 1950s exactly parallels the German sail training initiative with Pamir and Passat. ${ }^{21}$ Through an agreement with the National Union of Seamen, Calchas carried no deck crew except a bosun and carpenter. The 22 cadets carried out all the crew functions and were required to keep up their studies. Some tasks, such as rigging the heavy lift derrick involving work aloft, could be as taxing as some tasks on a square rigged ship. ${ }^{22}$ In one important respect these power-driven company training ships were similar to the German sail training ships. Both were based in commercial vessels and offered valuable experience in connection with cargoes and port operations.

After over 40 years experience with sail training ships feeding manpower to their commercial and military power-driven ships, the Germans must have been convinced that their approach bore fruit in the qualities as well as skills displayed at sea in later life.

1850-1950," The Great Circle [Australia] XXX, no. 2 (2008): 41-76.

20 E.C, Millington, Seamen in the Making: a Short History of Nautical Training (London, 1935), 170-175. An appendix, 175-85, reprints "The Cadet's Manual" issued by BISN, detailing the cadet's responsibilities and routine.

21 MV Calchas: built 1947 by Harland and Wolff, Belfast, for Ocean Steamship Co. (A. Holt \& Co.); gross tonnage 7639. Used as cadet training ship until 1956. She was succeeded in this role by MV Diomed: built 1956 by Caledon, Dundee, for Ocean Steam ship Co (A. Holt \& Co.); gross tonnage 7980 . Used as cadet training ship.

22 Interview (19 July 2003) with John Currie, who served in Passat with the author, and subsequently served in Calchas in 1954. 
However, the ship's managers were by no means completely altruistic. By carrying cargoes, the ships were earning freight at the same rates as tramp ships. ${ }^{23}$ True they made an extra financial investment in training accommodation aboard ship, subsistence and other services and facilities needed by the training dimension, but this would have been relatively small compared with the commercial viability of the ships, though of course this could vary with the prevailing level of freight rates. The intangible product of sail training will emerge again in the final section of this paper, but it is appropriate here to consider the published arguments, where sail training for careers at sea is interactive with that for character development.

Kurt Hahn, the great German educationalist who worked out his theories on the development of young people at his schools at Salem near Lake Constance (1920-33) and at Gordonstoun in Scotland (1934-53), took the widest view by arguing that the crises and lethargy of adolescence, so often viewed as an inevitable stage of development, could be countered by what he called "experience therapy, the cultivation of innate fights and absorbing personal interests, and training in self discipline." ${ }^{24}$ Athletic training played a key part:

through continuity of purposeful athletic training every normal boy or girl can be brought to attain the maximum standards within their reach. They can thereby develop resilience, stamina and powers of acceleration... The progress achieved often came as a surprise to the boy or girl in training: the experience of defeating their own defeatism remained a strengthening memory...[associated with this comes] the undefeatable spirit, the joy of movement, the power of compassion, the eager curiosity, the zest for building, the joy of exploration, the love of music painting or writing, the devotion to a skill demanding patience and care. ${ }^{25}$

It was this kind of thinking which lay behind the Outward Bound Sea School movement, the Atlantic College movement, and the Duke of Edinburgh's Award scheme, and the support Hahn gave to the 1950s German sail training initiative. An Australian youngster, commenting on his Outward Bound Course, effectively summed up what Hahn hoped to achieve:"The course was really great. Never before have I felt so hot, so cold, so wet, so dry, so happy, so deflated, so terrified, so elated, so tired, so fit, so utterly exhausted. All in all it was an incredible twenty six day experience." 26

Certainly, the more extended experience as a trainee in square rig could easily match the emotions expressed in this observation. Alex Hurst, who sailed in square rig in

23 Interview with the late Captain Martin Lee (who served in Passat in 1947), and was engaged in a major study of the commercial viability of ocean-going commercial sailing ships, 19191958, at the time of his death in 2004.

24 Hermann Röhrs, "The Educational Thought of Kurt Hahn," in Hermann Röhrs, ed., Kurt Hahn (Heidelberg, 1966; English edition: London, Routledge \& Kegan Paul, 1970), 123-136.

25 Kurt Hahn, "The Origins of the Outward Bound Trust", in David James, ed., Outward Bound (London, 1957), 1-17.

26 Quoted in Adrian Curlewis, "The Hahn prescription for 'the lawless, the listless, the couldn't-care-less fraternity," in D.A. Byatt (ed.), Kurt Hahn: an Appreciation of his Life and Work (Gordonstoun, Scotland, 1976), 67-70. 
the 1930s, put it this way:

The last square-riggers were magnificent, and I can testify from personal experience that, if they were wet on deck and heavy to work, and if they stopped dead in calm, the sheer grandeur of their sailing with fair wind in hard weather was utterly magnificent... Working aloft, often at night and in bad weather - perhaps in a blizzard with flooded decks gave ... [men] a great measure of personal initiative and self reliance. Inevitably, some fell by the wayside and came ashore, but the vast majority who stayed the course had, literally, found themselves. They not only knew their own capabilities as men, but had vastly increased them... Of the two attributes of the sailing ship: namely the seamanship of masts and yards, and character building par excellence, the former had become a doubtful quality, but the latter was known to be of unsurpassed benefit to any boy whether he went to sea or not. No one will deny the need of firm character in a man who follows the sea... there are still crises and disasters... a ship's officer must possess the necessary moral and physical fibre to cope with them. In short that is the argument for "sail training." Not only does it instill the necessary self reliance and power of decision, but it teaches a boy... the very run of the sea and a proper appreciation of the element in which he serves. ${ }^{27}$

The qualities sought by Hahn, and expressed by Hurst, can of course be developed through other activities, such as mountaineering. Underhill argues that a particular advantage of the sailing ship, particularly the square-rigged sailing ship, is that it:

is far more dependent on individual human effort than any powered vessel. A cadet not pulling his weight or failing to live up to the highest standards in a modern liner, would have very little effect on the well-being either of the ship or his fellow cadets. But a cadet who failed to play his part aloft on a yard could well endanger not only himself and those up there with him, but also the ship... aloft... there will be times when he must act instinctively on his own initiative, and act correctly too, for there will be no time to change his mind or seek advice... Such training must tend to develop his presence of mind... his self- reliance. ${ }^{28}$

These character building arguments, though they stand up in the context of general youth training, when offered to the exclusion of the transfer of seamanlike skills, may, in the context of a future seafaring career, underestimate the value of what may be learned aboard a sail training ship. The responses to the questionnaire may throw further light on this dimension when discussed in the final section of this paper.

The author approaches the discussion of career choice, occupational conditioning and training experience with a personal background of nearly a year aboard Passat in 1952, as an apprentice and deck officer in cargo liners, as a lecturer teaching Merchant Navy cadets and officers at Plymouth School of Navigation, and as mate aboard that school's small sail training ketch, Tectona (80 tons). In retrospect it is clear that, without

27 A.A. Hurst, The Sailing School-Ships (London, 1962), preface and Chapter 1. Hurst was writing as a Council member of the Sail Training Association about the Tall Ships races and the ships which took part, soon after their inauguration in 1956. 


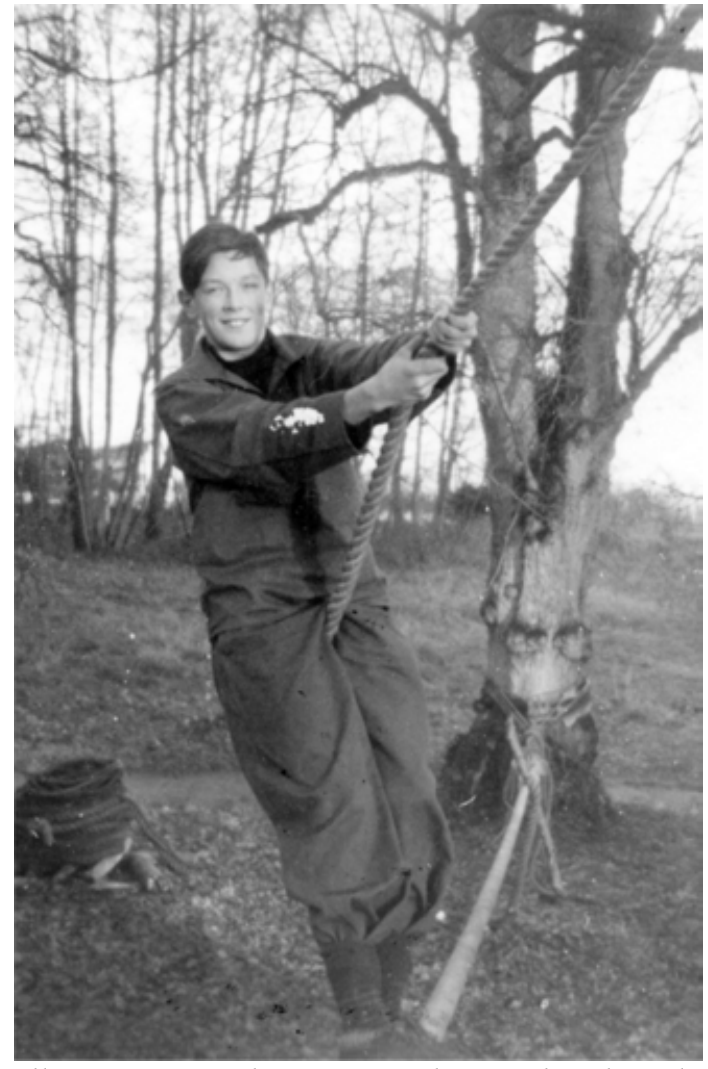

Illustration 4: Alston Kennerley on the obstacle course during "outward bound" training at Kurtschule Schloß Nehmten on the Plöner See, near Kiel, North Germany, early in 1952. [Photograph: Author.] school leaving age. In this the occupations of parents, especially fathers, and close relatives played a significant part. For seafarers, a parent at sea appeared to be a particularly strong influence. More recently another factor has come to the fore: the spread of recreational sailing. Other factors operated, particularly "relative deprivation," in which individuals from remote socially deprived communities are attracted to the relatively fuller shipboard life. Thus for the author having a grandfather who had been a ship's master, a father who was a radio officer at sea, and a mother who had been a clerk in a shipping company office, must be seen as triple influences. Further, as a five year old and again as a ten year old he underwent two passages of some six weeks to Australia and

Alston Kennerley, “An Exercise in Social Conditioning? The Joint Education and Training of Engineer and Navigator Cadets for Careers As Officers in in British Merchant Ships in the 1960s," The Northern Mariner/Le marin du nord XVI no. 4 (October 2006): 49-67.

30 Kennerley, "Occupational Socialisation: First Voyage in Passat." This overview is based on the more detailed arguments presented in that paper. 
back during the 1939-45 war aboard cargo liners of his father's shipping company. Finally from the ages of ten to sixteen he attended boarding school, which some commentators would consider an institution of relative deprivation, though in fact it was a useful preparation for ship board society.

Another element considered in 1994 is that of "occupational conditioning," the processes through which an individual is accepted into the workplace society of his chosen occupation. Socialisation is the process through which a person learns to live in society. It starts at birth and involves the transmission of particular cultures. As new layers of socialization are added so a person learns to live in several different social contexts: the home, the school, youth groups, the workplace. ${ }^{31}$ Workplace socialization can be particularly strong, involving behavioural patterns associated with the learning and performance of technological skills, including language, reinforced by a reward system: failure to behave and perform satisfactorily may lead to loss of employment and thus income. In seafaring, these elements are reinforced by the closed or "total" nature of shipboard society. Ships subject their members to an all pervading or "total" environment, tending to exclude completely other social environments in which the mass of people ashore move simultaneously.

From the sociological perspective of occupational conditioning, both attendance at some form of pre-sea school and undertaking a first voyage in a sail training ship can be considered as no more than structured socialization into the work place culture entirely for the benefit of the shipping industry. Shipowners gain men adjusted to work in the ship environment and thus further their commercial operations; more experienced crew members gain shipmates who know the language, contribute to the team effort, and know how to fit in. Whether this is the ultimate effect of Hahn's more elaborately expressed aims must await a future verdict.

The German initiative in 1950s combined special pre-sea training with service aboard Pamir or Passat. All the cadets selected attended an Outward Bound course, which in the case of Passat cadets lasted from October 1951 to January 1952. All passed through the special course run at Schloß Nehmten on the Plöner See (near Kiel) in Germany, but fifteen Germans and five British spent a month at a special course in Gordonstoun (where Hahn was still headmaster), and five other British attended a regular Outward Bound course at Aberdovey in Wales, before joining up with the rest of the cadets at Nehmten. The programmes at these residential courses covered the ground already noted for pre-sea schools. But they also included activity on the obstacle course, morning runs followed by cold baths, teamwork activities and attainment targets which were a feature of Hahn's ideas. The time in Germany was valuable for the English cadets for learning German behavioural patterns and enough of the language to be able to obey orders aboard their ships. The following extracts from the author's diary convey a little of the activity at Schloß Nehmten. ${ }^{32}$

31 Alston Kennerley, "Merchant Seafarers and their Homes in the Twentieth Century: a Study Drawing on British Sources," a paper presented at the $21^{\text {st }}$ International Congress of Historical Sciences, Amsterdam, 22-28 August 2010. 
Thursday 3 January 1952. Up at 6 am. No run [morning run and cold shower]. Breakfast at 6.45 and away at 7 [to go to Kiel to bend on Passat's sails]. Bent two sails in Kiel before lunch and emptied half a rail truck of sails. Pea soup for lunch. After [lunch] emptied rest of truck and bent on two more sails. Then went over ship and up to mizzen top and down the other side. Missed tea.

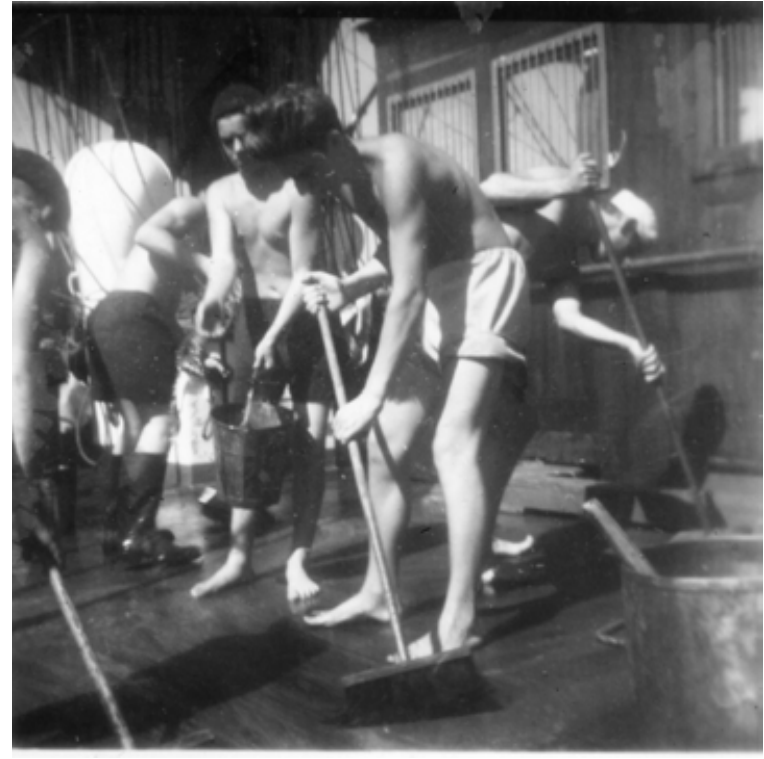

Illustration 5: Scrubbing the pine decks with caustic soda and sand, aboard four mast barque, Passat, in 1952. [ Photograph: Author.]
Friday 4 January 1952. Up at 7. Rowed to Bosau after breakfast, then to top of lake for wood [fuel for the stoves in the dormitories and the clothes and hot water boilers in the cellars]. Then cleaned boat out and jetty, while rest had obstacle course. Late for dinner. Pea soup and dumplings. Rowed down coast towards Plön. Hopf [now Kapt. Horst Hopf] let his spoon and fork fall in the water, but we got them out with an oar.

Sunday 6 January 1952
Backschaft today [peggy or mess
servant duties] Cleaned out room
and missed half of potato peeling.
None [of cadets on backschaft]
went to church. Two minus
points...Hopf and John [Currie]
cut my hair. Saved me 70
pfennig.

Sunday 6 January 1952 Backschaft today [peggy or mess servant duties] Cleaned out room and missed half of potato peeling. None [of cadets on backschaft] went to church. Two minus points...Hopf and John [Currie] pfennig.

Thursday 17 January 1952 Boats as usual. Just to Bosau. Code of Signals. Copied flags. Sport in afternoon. Canteen open.

Friday 25 January 1952 [on board Passat in Kiel]. All morning cleaning up for fourth mate [now Kapt. Rudiger Lenk]. Made his bunk, washed his basin, polished his brass and chairs, removed paint from his great coat and cap. Peeled spuds [potatoes] and bedded some down [in the potato locker under the bowsprit]. Free from 6 to 10 . Washed and tidied up. Last night on watch 1-3.

It will be apparent from the above that there was some involvement with Passat while she was completing her refit in Kiel. The cadets did not leave Schloß Nehmten to join the ship until she had been sailed round to Brake, a small port on the River Weser down stream from Bremen. Although with a ship's company of $94,{ }^{33}$ including 54 cadets,

this section come from this source.

33 Hanne Kühner, Passat: Botschafterin des Friedens (Lübeck, 2002). This contains eighty photographs taken by Kapt. Heuer augmented by extracts from the personal log kept Kapt. Rudi Wittenhagen, then serving as an able seaman. Other work about Passat in the 1950s include: Hellmut Jebens, Passat in Novembersturm: Bilder von der Letzen Grossen Fahrt 
Passat was heavily overmanned compared with under 30 when owned by Gustaf Erikson, cadets soon found themselves playing a full part in handling sail:

Friday 15 February 1952. 4-8 watch set all sail to t'gallants. Hard work. Fine morning. England not in sight. 15 knots [sic]. No engine. Good wind. Tired...Went aloft to upper t'gallants seeing to buntlines (main) [overhauling buntlines on main mast to reduce chaffing]. Captain watched -[I] did not know. [later] Set main royal. Not much wind. Engine going. [off] Land's End. Will not see England.

Friday 22 February 1952 Aloft on main to clear buntlines. Washed decks. Lowered fore royal. Heaved it up too much. Chain [tie between halliard and yard] broke. [halliard gin] Block came down amid sparks. Hopf on backstay fell and was hurt a bit.

Handling sail from the deck and the associated work aloft, loosing sail, furling and tending the buntlines, took priority over all other work and, at times, leisure. Instant response to orders such as "stand by to go about" was demanded, causing all on duty to run to their appointed stations. The task might take minutes or hours but invariably ended in tidying up the ropes now spread around the deck and attending the buntlines aloft. Apart from this there was a huge variety of tasks to be carried out as part of the ship's routine of watch keeping, maintenance and catering.

Wednesday 7 May 1952 12-4 No Watch. Potato sorting [throwing out the bad ones]. Little wind. 812 First hour wheel. Wind

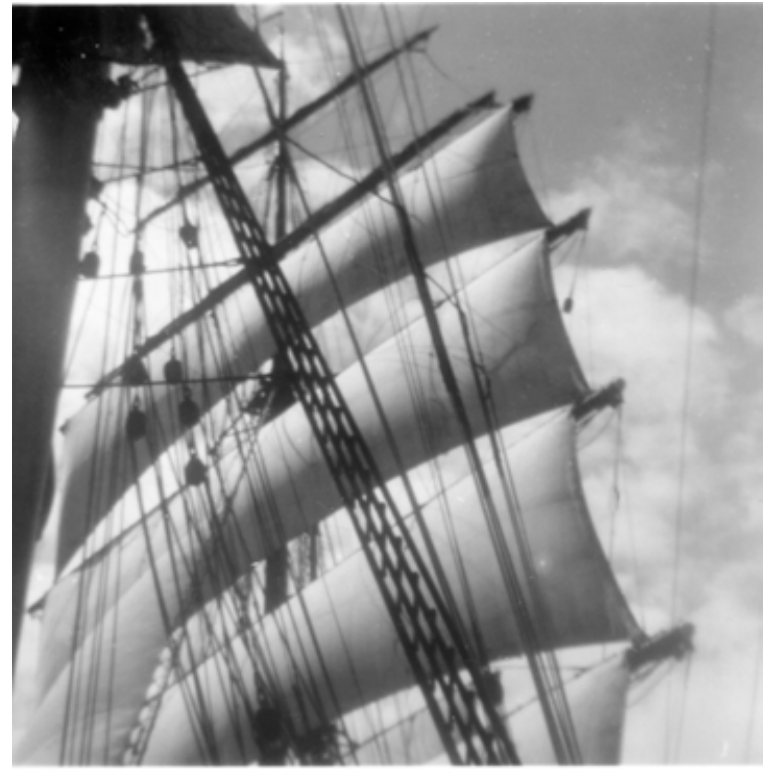

Illustration 6: Mizzen mast sails drawing well in a fresh breeze, aboard German four mast barque, Passat, in 1952. [Photograph: Author.] dropped completely; got 120 degrees off course. Log in. [Wheel] hard starboard. Rest of morning greasing mooring lines. A little wind now (1kn). JC [John Currie] dropped tin of oil from fore top. Just missed officers taking sights. Water lovely blue. One albatross. 6.30-12 Not much doing. Tied knots. Bared jigger [mast] then re-set it [sails]. Furled for t'gallant stay sail. More wind now.

Saturday 10 May 1952. From 12 midnight 3 watches. I am now in worst, 12-4. So am on watch for $9 \frac{1}{2}$ hours. Birthday today. From 4 onwards people kept on coming in on petty

(Kassel, Germany, ca. 1977); Kurt Grobecker, Passat: Das abenteuerlichte Leben eines Windjammers (Lübeck, 1991); Hans Domizlaff, ed., Das große Buch der Passat (Hamburg, 1980). For experience aboard Pamir in 1952 see Hilary Tunstall-Behrens, Pamir: a Voyage to Rio in a Four-Masted Barque (London, 1956). 
excuses so I had only a fitful sleep. At 8.30 [am] all hammocks had to be taken down to clean out. Just before midday lower tops'ls were set. All capstans are being overhauled. Washed decks. Watched Niels [Janasch, carpenter] making macramé for ditty bag.

Wednesday 14 May 1952 All sail set to upper t'galls. Good wind. Chipping [rust patches on ship's steel]. JC banged open his head and had three stitches. This evening U t'g's in. Finished fraying bag [ditty bag decoration]. Slept well to midnight. Handed in belaying list [names of all belaying pins].

Friday 30 May 1952 All sail in Morse, etc., for Ike [exercise in morse code with Second Officer Eizinger]. Painted companion rails 'till 2. Then wheel 1 man. Then davits [painting]. 3.30 [pm] Capt. Shoved box overboard and gave alarm man [overboard]. [Nos.] 3 \& 4 boats were lowered; engine stopped. Box picked up by Müller [senior second officer] in 3. Rest had lessons from Meteorologist. Did some navi[gation]. Nothing else.

Thursday 5 June 1952 Reduced to lower tops'ls and fore [sail] at midnight. Occasional squalls. Rain cold. 8.30 [am] extra work. [Breaking up] Coke [in fore peak] for most. I had to heave up water from fore drinking tanks for washing [crew clothes]. Then had to hang out midships washing. Coke not finished so we must work extra tomorrow. Painted brace winch (main). Then wheel.

Monday 20 October 1952 Got a good job this morning. The jigger stays'le had been chaffing on hatch four Samson posts and JD [John Dodds] and I were told to repair same with a yard of size 0 canvas and to sew pieces of tarred rope on each side. It has lasted all day as it is awkward to get at. Deck scrubbing is proceeding well, the after deck having been reached today.

With such a large crew double watches gave way to the three watch system in fair weather zones, and only essential work was done on Sundays. However that did not prevent cadets being called out to carry out maintenance tasks in their watch below, a practice called "field days" in British ships. Quite a lot of semi-formal instruction in a range of nautical subjects was carried out, but always on the open deck. In addition to the deck officers the ship carried two engineers, radio officer, meteorologist and doctor. There was a small hospital and surgery. Recreational activities included fancy rope work and ship model building. Social events included the crossing the line ceremony, playing records over the loud speaker system on Sundays, and the occasional fight when tensions were high.

Tuesday 4 March 1952 Backschaft. Finished off last night's dishes. Small pool made [on deck]. Neptune, wife, doctor, police, starman [boarded the ship. They] did everyone who had not crossed [the equator before] also JC and I [who had two previous crossings each]. Seamen had it worst. Marked in red. Turpentine in eyes; greasy fat pills from doctor; then ducked [in pool]. When clean certificate marzipan and weak drink issued. Watch now 48 .

Monday 19 May 1952 Was not woken for breakfast 'till 8. After backschaft finished off book. Would like to sail in ship like her. After afternoon backschaft stirred paint for Niels 


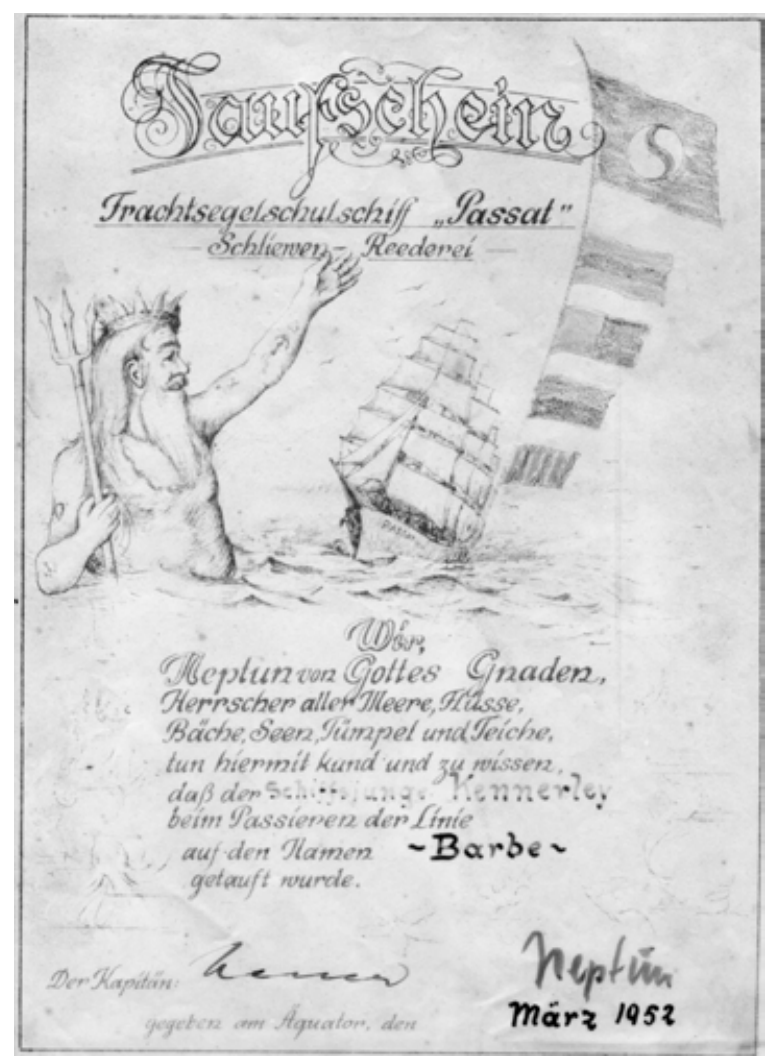

Illustration 7: This crossing the equator certificate issued to Alston Kennerley aboard Passat after submitting to the required tribute on 4 March 1952, despite having crossed the line twice before, in December 1940 and again April 1945! Company flag: Schliewen Reederei; signal letters DKEG. [Author's collection.]
[Janasch]. Read 'til five or so. Evening back[schaft]. 10 to 6 fight in earnest between Ebeling and Gadilhe. E. won. Raining heavily now. Should cross the line [northbound] about 7. Lot of people attending doc. Broken heads, poisoned fingers, etc. Butcher threw plate at ship's boy other day and cracked head a bit. All sail in now. No wind. Occasional doldrums squalls. Crawling along at about three knots.

Tuesday 27 May 1952 Ike on prowl [during night watch] and caught JC and I in corridor. Extra $1 / 2$ hour [on deck after change of watch]. Lower t'gan's'ls set and engine stopped at $6.30 \mathrm{am}$. Continued new bag. PM t'gan's'ls in and engine going again. Played some chess.

There is no doubt that the majority of the cadets aboard Passat in 1952 were well aware of their privileged position, and that such opportunities were increasingly rare. Evidence is found in the very keeping of the diary, and the level of detail which was generally maintained.

Nevertheless, having requested and been granted the second voyage, after ten months square-rig service, the four British cadets agreed the time had come to join the modern world of power-driven vessels in which they saw their future careers.

If the claims concerning the benefits of sail training have any substance, there must be some evidence to be found related to the subsequent careers of those who underwent such training as young men. The existence of a society whose members had served on Pamir or Passat in the 1950s offered a way of gathering career data and, especially, subjective opinions about their experience in sail. Through the generous cooperation of the management committee of the Pamir Passat Vereinigung (PPV), and especially the help of Kapitän Peter Kraus, a cadet with the author in 1952, a small questionnaire was circulated to PPV members in the spring of 2003. Out of 103 members who were eligible, 48 made returns. Amongst these are a few who served as seamen, a carpenter, a sailmaker, a doctor and a deck officer. But the great majority were cadets 
undertaking their first voyages. Owing to missing data the number of cases in Table 2 varies. As the prime objective was to obtain respondents' opinions on the value of their sail training experience, first in their further careers at sea, and second in careers ashore, the questionnaire is largely unstructured. To encourage returns it was restricted to a limited number of questions on one side of the sheet.

The inclusion of dates of birth in the PPV membership list has allowed the extraction of simple statistical data from the returns. This is of interest but cannot necessarily be considered typical owing to the limitations of the questionnaire, the small number of responses and the absence of any random element in their selection. Indeed, drawing a sample from the membership of an old shipmates' association is itself limiting owing to social factors. Some will have failed to respond out of inertia, but there may be others who have elected not to respond owing to a personal perception of having achieved a less successful career than other members. Conversely, those choosing to respond may do so through interest in the aims of the questionnaire or because they consider their careers to have been a success. Thus any examination of the outcome of the analysis of responses to the questionnaire must bear these biases in mind.

\section{Table 2 - Career Data of Seafarers Serving in Pamir/Passat \& Calchas/Diomed in the 1950s}

\begin{tabular}{|l|l|l|l|l|l|l|}
\hline & \multicolumn{3}{|c|}{ Pamir/Passat } & \multicolumn{3}{c|}{ Calchas/Diomed } \\
\hline & Max & Min & Mean & Max & Min & Mean \\
\hline Age joined Pamir/Passat (years) & 31 & 14 & 19 & 17 & & \\
\hline Time aboard Pamir/Passat (months) & 41 & 5 & 12 & 10 & & \\
\hline Time at sea after Pamir/Passat (years) & 44 & 0 & 15 & & & \\
\hline Total time at sea (years) & 45 & 0.5 & 17 & 52 & 5 & 16 \\
\hline Age left sea (years) & 64 & 20 & 35 & & & \\
\hline Time working ashore (years) & 44 & 0 & 32 & 44 & 0 & 31 \\
\hline Age retired (years) & 67 & 53 & 58 & & & \\
\hline Working Life (years) & 51 & 30.4 & 41 & 52 & 36 & 43 \\
\hline
\end{tabular}

Source: Responses to questionnaires; PPV membership list.

In the following analysis, there has been set against the Pamir/Passat data, some more limited data relating to the training, noted earlier, given in Calchas during the 1950s, and its successor, MV Diomed. The arrangement of an ad hoc meeting of men who had trained in those ships offered a last minute opportunity to circulate a questionnaire similar to that sent to PPV members. Sixteen responses were received. The same caveats apply to these as to those of PPV members.

The mean age (Table 2) at which respondents joined Pamir/Passat in 1952, 19, is relatively high, partly through the inclusion of men having previous sea service, partly 
because of the disruption to careers caused by the recent war, and partly through the appeal of the opportunity to serve in sail. That of Calchas/Diomed men is more consistent, representing the company's policy of recruiting youngsters having good school leaving qualifications obtained at about 16 years of age. The mean time aboard Pamir/Passat, 12 months, suggests that the typical respondent made two voyages, as was the case with the author. The maximum of 41 months reflects a respondent who returned to serve in more senior capacities. It was company policy that all Calchas/Diomed cadets should make two voyages, on a 50 per cent turnover basis, to allow transfer of experience. Hence the mean of 10 months service. The remaining responses summarized in Table 2 are interactive with each other. Typically Pamir/Passat respondents spent about 17 years at sea, leaving in their 30s, and pursued another career for about 30 years, before retiring at about 60 . The mean sea service from this very small sample works out at a very similar 16 years for Calchas/Diomed men, and for those working ashore, a similar career of 31 years.

Schloß Nehmten was a temporary pre-sea school to which all those chosen to sail in the first post war voyages were sent. It was replaced by the school at Priwall-Travemünde, which of course maintained a close relationship with Pamir/Passat during their operation in the 1950s. That over half the respondents attended these establishments is to be expected (Table 3 ). Those who did not attend a pre-sea school had either served at sea previously or had experience (one had served on Rhine barges) considered equally acceptable. It was from the foundation of the Outward Bound Sea School at Aberdovey, by Laurence Holt, under the influence of Kurt Hahn, that it had been Blue Funnel policy to send all the apprentices the company engaged on one of its 26 day pre-sea courses. It is surprising that one Calchas/Diomed respondent did not attend such a course. It is significant that 83 percent of Pamir/Passat respondents passed the A5/first mate's foreign-going certificate, and 76 percent the A6/master's certificate, and that similar ratios apply to Calchas/Diomed men. These qualifications, and that 21 (46 percent) of the Pamir/Passat respondents held command, may be indicative of the bias in the survey, but the command return may reflect the opportunities for command in smaller vessels under the West German flag in the 1950s. Five (31 percent) of the Calchas/Diomed 
respondents held command. Owing to the loss of the Pamir in 1957 with 80 lives, and the continued operation of Passat until 1958, the imbalance of responses in favour of Passat men amongst the Pamir/Passat respondents was to be expected.

Table 3 - Pre-Sea Training, Training Ships and Licenses

\begin{tabular}{|l|l|l|l|l|}
\hline & \multicolumn{3}{|l|}{ Pamir/Passat } & \multicolumn{2}{l|}{ Calchas/Diomed } \\
\hline & No. & Percent & No. & Percent \\
\hline Pre-sea training at Priwall Travemünde & 16 & 35 & & \\
\hline Pre-sea training at Schloß Nehmten & 9 & 20 & & \\
\hline Pre-sea training at Schulschiff Deutschland & 7 & 15 & & \\
\hline Pre-sea training at Ottward Bound Aberdovey & 14 & 87 & & \\
\hline Pre-sea training at other sea schools & 4 & 9 & 1 & 6 \\
\hline No pre-sea training & 7 & 15 & 1 & 6 \\
\hline Served in Pamir or Calchas & 15 & 33 & 15 & 94 \\
\hline Served in Passat or Diomed & 27 & 59 & 1 & 6 \\
\hline Served in both Pamir \& Passat & 4 & 9 & & \\
\hline Licenses gained: $2^{\text {nd }}$ Mate Foreign-Going & 16 & 100 & & \\
\hline Licenses gained: A5/ 15t Mate FG & 38 & 83 & 14 & 87 \\
\hline Licenses gained: A6/ Master FG & 35 & 76 & 10 & 62 \\
\hline Held command in merchant ships & 21 & 46 & 5 & 31 \\
\hline
\end{tabular}

Source: Responses to questionnaires.

A quarter of the respondents served their whole working lives in the merchant marine (Table 4). The proportion is rather smaller amongst Calchas/Diomed men. If those that had second careers as sea pilots, in the coastguard, or as naval officers are added to these, half of Pamir/Passat men may be considered as having followed sea careers all their lives, but only a third of Calchas/Diomed men. A further quarter of Pamir/Passat respondents opted for second careers in sea-related occupations ashore, as did nearly half of Calchas/Diomed respondents. Allowing for the possible bias in the surveys, three quarters of those who served in the training ships followed their careers in the wider maritime industry, many in positions of some responsibility. A number of Pamir/Passat respondents who left the merchant service for other employment, after retirement returned to the merchant service for a period in command. Several have commanded sail training ships currently in operation such as the Alexander von Humboldt.

Almost without exception those who served in Pamir/Passat have commented positively on their pre-sea training regardless of which establishment they attended. Several used phrases such as "necessary," "you needed it," "excellent start up." Some 
Table 4 - Full Merchant Service Careers and Occupations After Part Careers in Merchant Service

\begin{tabular}{|l|l|l|l|l|}
\hline & \multicolumn{2}{l|l}{ Pamir/Passat } & \multicolumn{2}{l|}{ Calchas/Diomed } \\
\hline & No. & Percent & No & Percent \\
\hline Career wholly in Merchant Service & 10 & 25 & 2 & 13 \\
\hline Second career as Sea pilot & 5 & 11 & 2 & 13 \\
\hline Second career as Nautical Teacher & 4 & 9 & & \\
\hline Second career as Naval Officer & 5 & 11 & & \\
\hline Second career in Coastguard/R. Police/Fish. Insp. & 2 & 4 & 1 & 6 \\
\hline Second career in other sea sea-related occupations & 7 & 15 & 7 & 44 \\
\hline Second career in School Teaching & 3 & 7 & & \\
\hline Second career in other occupations & 6 & 13 & 4 & 25 \\
\hline
\end{tabular}

Source: Responses to questionnaires; PPV membership list

pointed to learning basic skills, physical fitness, and coping with communal life. A seaman who had served in fishing boats but had not undergone a pre-sea course clearly envied the cadets their preparation. Another commented on training in a stationary ship as beneficial because it was a real ship. In marked contrast to these favourable observations are those of Calchas/Diomed respondents amongst whom views were much more polarized. One third of respondents took a negative viewpoint, though another third expressed themselves in positive terms similar to those of the Pamir/Passat respondents. Certainly having had a boarding school education served as a preparation for communal life aboard ship, while schools with strong games and athletics traditions provided physical fitness. Further, participation in youth movements such as scouting was mentioned as reducing the importance of Outward Bound courses. Clearly the value of pre-sea training must be related to previous personal experiences as well as to service as a young man in a training ship. One other difference between the British and Germans was the five respondents who had attended pre-sea courses of various durations in nautical schools in addition to the Outward Bound course. At these establishments, although offering boat work and seamanship, there was a strong emphasis on academic nautical studies, usually taken at least to the level of the British Second Mate's examination.

The question of the value of time in a training ship for future careers in powerdriven ships led to much more positive responses from Calchas/Diomed respondents, who were uniformly supportive. Power-driven vessel seamanship skills are mentioned, but almost seem taken for granted. The terms which stand out are responsibility, self reliance, confidence, team work, man management, high standards, discipline, comradeship, self esteem. Indeed, these are the collection of qualities which Kurt Hahn was keen to see developed. In the responses from Pamir/Passat men one senses a reluctance to admit any discontinuity between sail and power-driven vessel requirements. 


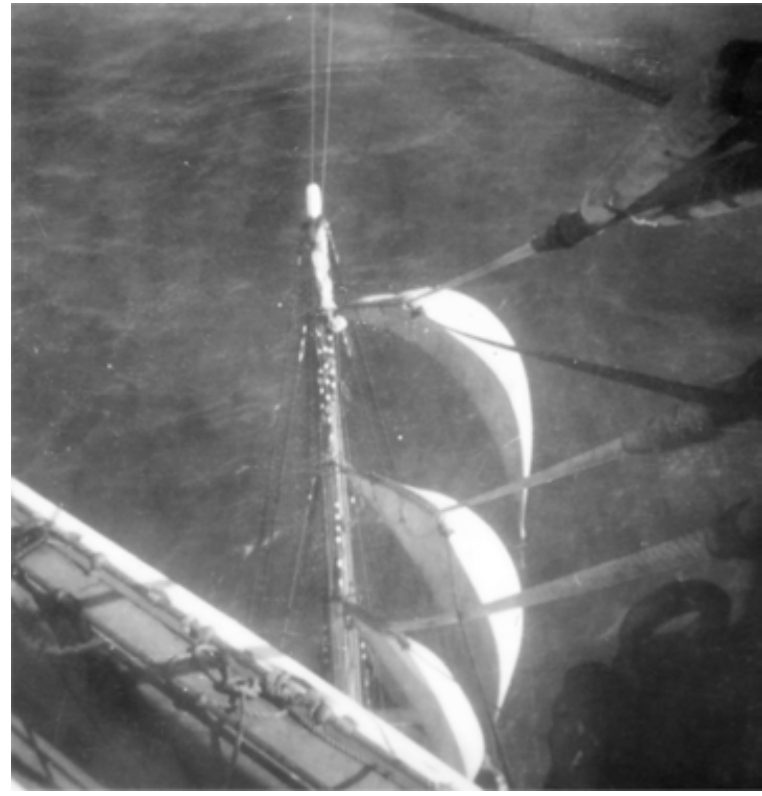

Illustration 9: The bowsprit and head sails of German four mast barque Passat from the fore cross trees 150 feet above, in 1952. [Photograph: Author.]
Certainly much mention is made of practical seamanship skills being superior, but the most frequent comment concerns the appreciation of the elements, wind and sea, which sail training engendered. This was seen as applicable many years later when in command. Only one respondent had the courage to say "not necessary," though those who ignored this question may possibly be added to this minority. However, sail experience was seen as useful in getting employment with major shipping companies. In naming the qualities mentioned by Calchas/Diomed men, Passat/Pamir men are in agreement that training ship experience is useful for future sea-going careers. Perhaps the comment that "emotionally, I would not like to miss the time in Passat" sums up the support for sail

training.

The final question concerned the value of training ship experience to shore employment. The reduced number of responses suggests that respondents had difficulty with this question. Where the job had a connection with the sea, most obvious in pilotage and naval careers, but also valid in terminal management and ship broking, making a connection was not too difficult. For careers not perceived as having a sea connection, some respondents were content to record "no connection." However a significant number of respondents were prepared to identify transferable characteristics not especially related to the sea, which their sea training had been responsible for developing. Here again it may be argued that the attributes identified by Kurt Hahn and others are the key abilities being identified. In this there is little difference between the responses from either kind of training ship. One response was "problematical." Though unexplained, this suggests that the people this former Calchas man found himself working with did not display the social characteristics which his training had led him to expect amongst colleagues. Perhaps it is the case that amongst the working population there is less leadership, less willingness to take responsibility, less consideration for others, less initiative, and less willingness to contribute to a team effort.

This paper has addressed sail training from three directions: operational context and purpose, personnel experience, and relationship to future careers. It has shown that the German initiative of the 1950s had a sound basis in the practice and technology developed in the first half of the twentieth century, and that, finance allowing, it was a useful, though not essential, way of imbuing general skills and transferable qualities for more senior 
employment in the merchant service. The analysis of theoretical comments on sail training demonstrates a connection with broader concepts of character development in young people. The section on the personal experience of the author, drawing upon earlier work, drew attention to the influences on occupational choice and to the objectives of initial training concerned with occupational socialization. Quotations from the author's personal diary during his time in Passat went some way to illustrating the physical activity, dangers, great variety of tasks a seaman must undertake, the detailed knowledge of the ship and its rigging, which was required, and the social relationships on board ship. The relationship of sea training, both in sail and in power, was studied in the final section through a detailed analysis of the responses to questionnaires, with particular reference to future employment, in power driven vessels, and in shore employment. This analysis is at best indicative. It may be flawed owing to the self-selecting nature of the respondents, and the limitations of unsophisticated questionnaire formulation. Nevertheless, it is argued that in terms of the broad range of personal skills sea training engenders, and the transfer possible into other walks of life, such a training for young people is worth the cost and the effort, whether for seafaring careers or careers in other fields of human endeavour.

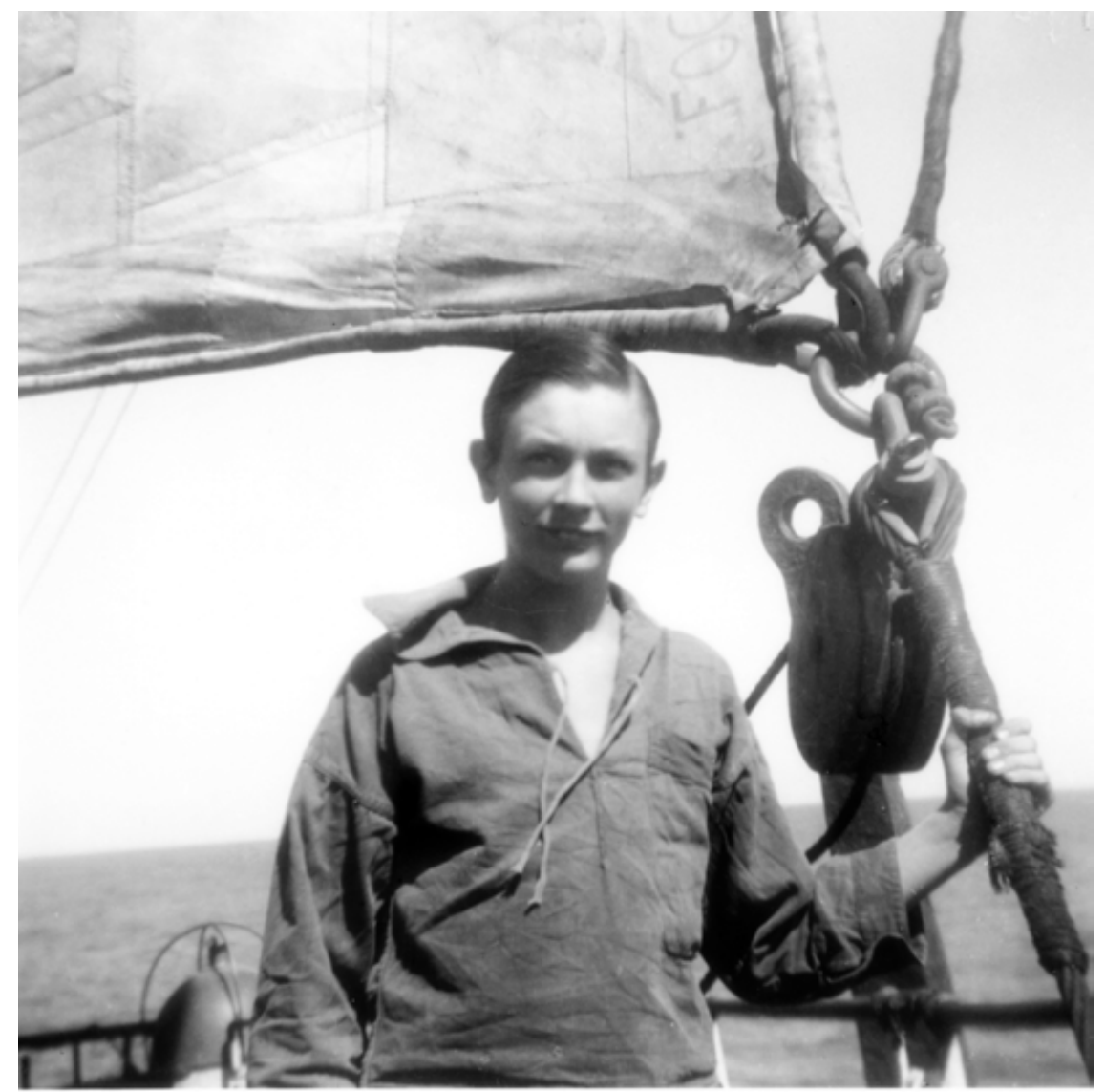

Illustration 10: Alston Kennerley on the fo 'c's 'le of the German four mast barque Passat 1952.In the background (left) is the port side light house, and the stock of the port anchor. The ship is close hauled on the port tack. [Photograph: Author.] 


\title{
CNRS 2011 Conference and AGM
}

\section{Nautical Voyages}

\section{Cruising, Yachting and Small-boating Through the Ages}

\author{
Ottawa - 18-21 May 2011
}

\section{Call for Papers}

Whether for commerce, exploration, war fighting or simple pleasure cruising, travel on water - oceans, seas, lakes, rivers and canals - takes many forms and has been a staple of human transportation for at least as long as the wheel. Papers are invited to address any variety of perspectives on related themes involving ships, people, ports or trade. The Society reserves first right of refusal for publication in our journal The Northern Mariner / Le Marin du nord or newsletter Argonauta as appropriate, and new scholars are invited to apply for the Panting Bursary to support travel to deliver a paper (details on our web-site: www.cnrs-scrn.org).

Ottawa, the nation's capital, is strategically placed for this conference, located at the confluence of the Gatineau and Rideau with the Ottawa Rivers, and at the northern mouth of the UNESCO Heritage Site Rideau Canal. Mid-May also is the height of the Tulip Festival. Conference sessions and banquet will transpire in the historic quarters of HMCS Bytown, since 1943 the Wardroom (officers mess) for naval officers serving in the national defence headquarters, and there will be an optional evening dinner cruise on the Rideau Canal. A variety of accommodation options are available in the immediate area.

Paper proposals and administrative enquiries should be directed to:

Dr Richard Gimblett

CNRS 2011 Conference Coordinator

49 South Park Drive, Ottawa, Ontario, K1B 3B8

Telephone: 613-830-8633

email: richard.gimblett@rogers.com

Further details will be published as soon as they are available on our conference webpage at http://www.cnrs-scrn.org 